\title{
Олексій Онуфрієнко
}

Дніпропетровський регіональний інститут державного управління Національної академії державного управління при Президентові України

\section{«День прийдешній» цифровізації публічного врядування у США: стратегія штучного інтелекту}

Проаналізовано Стратегію штучного інтелекту Міністерства Оборони США (2018 р.) як пілотного проєкту перспективної е-модернізації публічного сектору цієї держави, визначено ії місце серед інших ініціатив із цифровізації публічного врядування чинної адміністрації Президента США, з'ясовано іiі специфічну публічно-адміністративну логіку, окреслено специфіку цього проєкту крізь призму завдань модернізації публічного врядування у трансформовуваних суспільствах.

Ключові слова: иифровізаиія публічного сектору США, відкритий уряд, е-урядування, стратегія штучного інтелекту

\section{The "coming day" of digital government in the United States: a strategy for artificial intelligence}

\section{Oleksii Onufriienko, Dnipropetrovsk Regional Institute for Public Administration National Academy for Public Administration under the President of Ukraine}

The US Department of Defense Artificial Intelligence Strategy (2018) as a pilot project of promising e-modernization of the public sector of this country is analyzed, its place among other initiatives on digitalization of public administration of the current US Presidential Administration is determined, its specific public-administrative logic is clarified. the specifics of this project through the prism of the tasks of modernization of public governance in transforming societies.

Keywords: digitalization of the US public sector, open government, e-government, artificial intelligence strategy

I ніціативи Президентської адміністрації Д. Трампа стосовно подальшої цифровізації публічного сектору США концептуально не виходять за межі теоретико-ідеологічної основи моделі «Відкритого уряду», запропонованого та великою мірою втіленого адміністрацією Президента Б. Обами. Зокрема, пропонована Стратегія Федеральних Даних (Federal Data Strategy) по суті $є$ подальшою конкретизацією ідей «Відкритого уряду», що будується на тих самих принципах: прозорість, відповідальність, співробітництво. Утім, в активі «Порядку денного» Президента Д. Трампа (2018 p.) як стратегічного політичного документа $€$ й оригінальні здобутки, зокрема факт розкриття основних проблем сучасного публічного управління та публічної служби в США крізь призму оцінювання динаміки інформаційного обміну та описування перешкод зворотного зв'язку між державою та громадськістю, що $є$ абсолютно виправданим в інформаційному суспільстві.
Слід відзначити й дійсно інноваційні ініціативи чинної адміністрації. Так, у 2019 р. міністерством оборони США було оприлюднено «Стратегію штучного інтелекту». Розуміючи штучний інтелект (ШІ) на його сучасному рівні розвитку як здатність обчислювальної техніки (машин) виконувати функції, що звичайно потребують людських розумових здібностей, зокрема розпізнавати образи, вчитися на власному досвіді, робити висновки та прогнози, нарешті, ухвалювати рішення та діяти на їх основі (Summary of the 2018 department of defense artificial intelligence strategy. Harnessing AI to Advance Our Security and Prosperity, 2019, p. 5). Упровадження ШІ в діяльність Міністерства оборони (та, додамо, грунтуючись на досвіді дослідження еволюції е-урядування в США, й інших державних агенцій у перспективі)це швидкий, ітеративний та відповідальний процес для того, щоб покращити якість ухвалення рішень військовими та здійснення ними операцій на ключових напрямах (Summary of the 2018 department of defense 
artificial intelligence strategy. Harnessing AI to Advance Our Security and Prosperity, 2019 , p. 7). Одними 3 основних напрямів використання технологій ШІ визнається передбачувальне обслуговування та логістика (predictive maintenance and supply) (Summary of the 2018 department of defense artificial intelligence strategy. Harnessing AI to Advance Our Security and Prosperity, 2019, p. 7), використання систем розпізнавання образів для покращення загальної ситуаційної обізнаності та виявлення неочевидних для людини-оператора загроз в усіх сферах застосування (від віртуального простору до реального поля бою) та підтримка ухвалення рішень у військовій сфері у формі обчислювання тактик та стратегій в унікальних бойових ситуаціях (Summary of the 2018 department of defense artificial intelligence strategy. Harnessing AI to Advance Our Security and Prosperity, 2019, p. 7).

Вже на цих етапах розгортання змісту аналізованого документа простежуються прямий зв'язок зі змістом «Порядку денного Президента в галузі управління» (The President's management agenda, 2018), a саме із загальнодержавною ініціативою стосовно збереження та нарощування кадрового резерву фахівців у сфері IT та проголошеною Президентом Д. Трампом метою підвищення якості ухвалення рішень державними агенціями. Це ілюструє системність та масштабність ініціатив Президентської адміністрації, що реалізуються не тільки в суто виконавчих агенціях, але й на рівні Міністерства Оборони, де власне стратегія штучного інтелекту, як уявляється, стане локомотивом для всієї системи органів публічного управління. Пріоритетизація оборонної проблематики узгоджується відповідно до зменшення військової присутності США у світі і насамперед на Близькому Сході, яке розпочалося ще за каденції Президента Б. Обами, зростання рівня міжнародної нестабільності та загрози обороноздатності держави, що пов'язується 3 активізацією нових регіональних держав-лідерів. Невипадково факти значних інвестицій Росії та Китаю в ІТ-технології в оборонній сфері, які до того ж, за думкою Міністерства Оборони США, у певній частині $\epsilon$ такими, що викликають питання сто- совно їх відповідності нормам міжнародного права та практиці забезпечення прав людини, згадуються вже у преамбульній частині Стратегії та інтерпретуються як загроза технологічному лідерству Сполучених Штатів (Summary of the 2018 department of defense artificial intelligence strategy. Harnessing AI to Advance Our Security and Prosperity, 2019, p. 5).

Конкретною інституційною ініціативою у цьому напряму стало утворення Об'єднаного центру штучного інтелекту (Joint Artificial Intelligence Center, JAIC) - центру координації всього спектру заходів, передбачених Стратегією штучного інтелекту Міністерства Оборони США (Summary of the 2018 department of defense artificial intelligence strategy. Harnessing AI to Advance Our Security and Prosperity, 2019, p. 9-10), який об'єднує «критичну масу експертних компетентностей» для того, щоб допомогти Міністерству Оборони використати якісно нові можливості, які надає ШІ. Центр, з адміністративної точки зору, має координувати упровадження IT-технологій штучного інтелекту в усі сфери військової діяльності.

Одночасно з уже наявним у джерелах досить тривіальним політичним трактуванням означених ініціатив неможливо не побачити суто публічно-адміністративний зміст пропонованої Пентагоном Стратегії, який до того ж заслуговує на уважніший розгляд. 3 точки зору публічного врядування вона пропонує завершену модель IT-модернізації міністерства Оборони внаслідок структурних, інституціональних, інструментальних та концептуальних новацій. План-схема розбудови такої моделі виглядає так:

- розгорнуте цілепокладання в преамбулі та телеологічній частині Стратегіï, логічно i несуперечливо пов'язане із загальнодержавними інтересами: «ШІ буде корисним як для міністерства, так і для держави» (Summary of the 2018 department of defense artificial intelligence strategy. Harnessing AI to Advance Our Security and Prosperity, 2019, p. 6) та «Порядком денним в галузі управління» Президента Д. Трампа;

- формування інструментарію, необхідного для досягнення означених цілей за допомогою активної нормотворчої, інституціональної та кадрової активності. 
Утворення Об'єднаного центру штучного інтелекту для координації всіх тематичних ініціатив як адміністративного стрижня, що підтримує та скеровує розбудовувану систему «цілі-засоби»;

- забезпечення належного фінансування за допомогою окреслення широкого кола фондів, причому як традиційних для цієі сфери на кшталт тих, якими керує Управління перспективних дослідницьких проєктів Міністерства Оборони США (Defense Advanced Research Projects Agency, DARPA) (Summary of the 2018 department of defense artificial intelligence strategy. Harnessing AI to Advance Our Security and Prosperity, 2019, p. 16), так і нових джерел та механізмів;

- установлення режиму активної взаємодії із зацікавленими контрагентами, зокрема іншими державними агенціями та неурядовими організаціями (Summary of the 2018 department of defense artificial intelligence strategy. Harnessing AI to Advance Our Security and Prosperity, 2019, p. 6), як частковий прояв відкритої моделі публічної служби та конвергентної форми публічного управління (відтак, новостворені структури жодним чином не замикаються на собі й уникають тим самим утворення інформаційних силосів за рахунок активного інформаційного обміну);

- нарешті, модельні перспективи пропонованої системи техніко-інформаційної модернізації Міністерства Оборони: в разі ii успішної практичної апробації слід очікувати поширення кращого досвіду на всі державні агенції США. «Піонерський підхід до Ш» (Summary of the 2018 department of defense artificial intelligence strategy. Harnessing AI to Advance Our Security and Prosperity, 2019, p. 6), безумовно, буде використаний усією системою публічного управління.

3 точки зору українського дослідника, що добре розуміє виклики, які стоять на порядку денному у процесах реформування вітчизняної системи публічного управління загалом і завдання цифровізації публічної служби та її сервісів, зокрема, особливу цікавість мають викликати наступні спостереження та висновки. По-перше, навіть усталена і відносно стабільна демократія з глибоко вкоріненими традиціями відкритої емпіричної публічної служби не стоїть осторонь структурним та інституціональним новаціям, повертаючись у разі потреби до активного державотворення у вигляді формування нових органів публічного адміністрування та джерел фінансування проголошених ініціатив, зокрема за рахунок гнучкої системи нових спеціалізованих фондів. По-друге, нова ініціатива розгортається відповідно до неодноразово апробованих управлінських моделей, реалізацію яких можна спостерігати, досліджуючи розгортання е-урядування як сучасної форми публічного управління у США в інформаційну епоху. По-третє, новостворені органи обов'язково вбудовуються в систему налагодженої міжагенційної та позаурядової взаємодії, як інформаційної, так і фінансової, що дозволяє уникнути їх ізолювання та залучити інститути громадянського суспільства до активної участі в предметній діяльності агенцій. Це відбувається навіть у структурах Міністерства Оборони США з відомими обмеженнями режиму вільного обігу інформації (та втаємниченням значної їі частини), властивими цьому відомству. По-четверте, амбітність реальних державних проєктів США в IT-cфері важко переоцінити: окремий інструментарій штучного інтелекту, нехай й у спрощеній інтерпретації, зав'язаній на тесті Тюрінга, вже використовується одним із провідних міністерств 3 перспективами відповідного оновлення е-урядування в загальнодержавних масштабах, зокрема стосовно задач розпізнавання образів, подальшого вдосконалення систем захисту від кібератак за рахунок евристичного аналізу та покращення логістики. Цей досвід, як мінімум, має бути вивчений під час цифрової модернізації вітчизняного публічного управління та розбудови системи е-сервісів, тим більше, що сучасна інформаційно-технологічна глобалізація дозволяє «перестрибнути» через кілька послідовних технологічних ітерацій для того, щоб втілити одну 3 найсучасніших технологій. По-п’яте, придбання відповідних технологій здійснюється на основі механізму тендерів, який добре себе зарекомендував на рівні всієї системи державних 
агенцій. Наявність серед учасників конкуруючих флагманів IT-індустрії (Amazon, IBM, Microsoft, Oracle тощо), що змагаються за контракти, які обраховуються мільярдними сумами, неминуче призводить до критики методики обрання переможців тендерних змагань (з боку переможених) та публічних обговорень якості державної політики IT-закупівель.

Таким чином, цифровізація органів публічного управління у США, паралельно 3 більш традиційними процесами е-модернізації публічного сектору і відомою мірою незалежно від них, результує також у цікаві та інноваційні галузеві проєкти, котрі внаслідок своєї специфічності, дійсно стратегічних горизонтів, відсутності безпосереднього зв'язку із загальною практикою адміністрування та суто технічної нетривіальності зазвичай не потрапляють до поля зору дослідників, що репрезентують науку публічного управління. Утім, упевнені, що такі ініціативи заслуговують на увагу, оскільки вони, як мінімум, поглиблюють сучасне уявлення як про багатоаспектність електронного врядування в сучасних державах, що є лідерами у сфері інформаційно-технологічного розвитку, так і про останні актуальні тенденції, про «післязавтрашній день» IT-технологій публічного сектору, що буде корисним для трансформовуваних суспільств, котрі прагнуть модернізуватися, орієнтуючись на день сьогоднішній у розвитку е-урядування провідних держав світу.

\section{БІБЛІОГРАФІЧНІ ПОСИЛАННЯ}

The White House. (2018). The President's management agenda. Washington, DC: Author. Retrieved from https://www.whitehouse.gov/wp-content/uploads/2018/03/The-President\%E2\%80\%99s-Management-Agenda.pdf

U.S. Department of Defense. (2019). Summary of the 2018 department of defense artificial intelligence strategy. Harnessing AI to Advance Our Security and Prosperity. Washington, DC: Author. Retrieved from https://media.defense.gov/2019/Feb/12/2002088963/-1/-1/1/SUMMARY-OF-DOD-AI-STRATEGY. PDF?fbclid=IwAR0iPoHeBD-hjWG6spK_6C9nJjADlqguh9ZwV_gHYRpUrq7M0Zj7dsbvTEA 